\title{
Practical Guide to the New Oral Anticoagulants
}

\section{Turiel $\mathbf{M}^{*}$, Galaverna S, Colombo C, Gianturco L and Stella D}

IRCCS - Istituto Ortopedico Galeazzi, Milan, Italy

\section{Keywords: Atrial fibrillation; Anticoagulation; Pharmacotherapy}

\section{New Oral Anticoagulants}

Over the last few years, new oral anticoagulants (NOACs) have been developed and marketed for the treatment of non-Valvular Atrial Fibrillation (NVAF), Deep Venous Thrombosis (DVT) and, more recently, for pulmonary embolism (PE).

The rationale underlying these new therapies is that they reduce the risks of embolic stroke and bleeding. Standard dicumarol therapy is characterised by a narrow therapeutic window that is reflected in the need for frequent monitoring of the international normalized ratio (INR). The therapeutic INR range in these diseases is between 2 and 3 because an INR of $>3$ increases the risk of bleeding, whereas an INR of $<2$ means the a suboptimal prevention of ischaemic stroke [1] (Figure 1 ), and only a small percentage of patients fall into this category. Furthermore, the anticoagulant power of dicumarols is modified by food, drugs and malabsorbition syndromes.

The risks of embolism and bleeding are respectively assessed using the: $\mathrm{CHA}_{2} \mathrm{DS}_{2}$ Vasc score [2] and the HAS-BLED score [3] (Tables 1 and 2).

Dabigatran, rivaroxaban and apixaban are three new drugs that have different mechanisms of action, daily doses, and metabolic and elimination profiles.

- Dabigatran (Pradaxa) is a direct thrombin inhibitor (it inhibits factor II) that has a half-life of about 12-14 hours and needs to be administered twice daily. It partially binds plasma proteins and can therefore be partially dialysed. Pradaxa is only eliminated renally: it is therefore contraindicated in patients whose creatinine clearance is $<35 \mathrm{~mL} / \mathrm{min}$, and a reduced dose is mandatory when it is $<50 \mathrm{~mL} /$ min.

- Rivaroxaban (Xarelto) is a direct factor X inhibitor with a half-life of 5-13 hours, but completely binds plasma proteins. It is administered once daily with evening meal in NVAF patients, and twice daily in those with DVT or PE. It is eliminated by the kidney and liver, and can be used at a lower dose if creatinine clearance is $<50 \mathrm{~mL} / \mathrm{min}$ and $>15 \mathrm{~mL} / \mathrm{min}$ in NVAF patients; its use should be avoided in DVT/PE patients whose creatinine clearance is $<30 \mathrm{ml} / \mathrm{min}$.

- Apixaban (Eliquis) is a direct factor X inhibitor with a half-life of 9-14 hours, but completely binds plasma proteins. It is administered twice daily and eliminated by kidney and liver. It should not be used if creatinine clearance is $<15 \mathrm{~mL} / \mathrm{min}$, and the dose should be reduced if it is $<30 \mathrm{~mL} / \mathrm{min}$.

The efficacy (primary endpoint: ischaemic or hemorrhagic stroke, systemic embolism) and safety (major bleeding) of these new drugs have been assessed in three clinical trials, [4-6] the results of which are summarised in Table 3 .

According to the ESC guidelines, [7] NOACs should be preferred to dicumarols in all patients with NVAF and a CHA2DS2Vasc score of $>1$ (Figure 2).

\section{ESC guideline indications}

1) Antithrombotc therapy (thromboembolism prophylaxis) is recommended for all male and female patients with atrial fibrillation (AF), except those at very low risk (age $<65$ years and AF alone) or with contraindications (class IA).

2) The choice of antithrombotic therapy should be based on an evaluation of the absolute risk of stroke/embolism and bleeding in each patient (class IA).

3) The CHADS VASc score is recommended for risk evaluation in patients with NVAF.

4) Females aged $<65$ years with AF alone (a CHADS VASc score of 1 taking gender into account) are at low risk and antithrombotic therapy should not be considered (class IIa B).

5) Antithrombotic therapy is not recommended in patients with a CHADS VASc score of 0 (age $<65$ years with AF alone) who are low risk or without risk factors (class IB).

6) Unless contraindicated (and after evaluating bleeding risk and patient preference), antithrombotic therapy one of the following is recommended in patients with a CHADS VASc score of $>2$ :

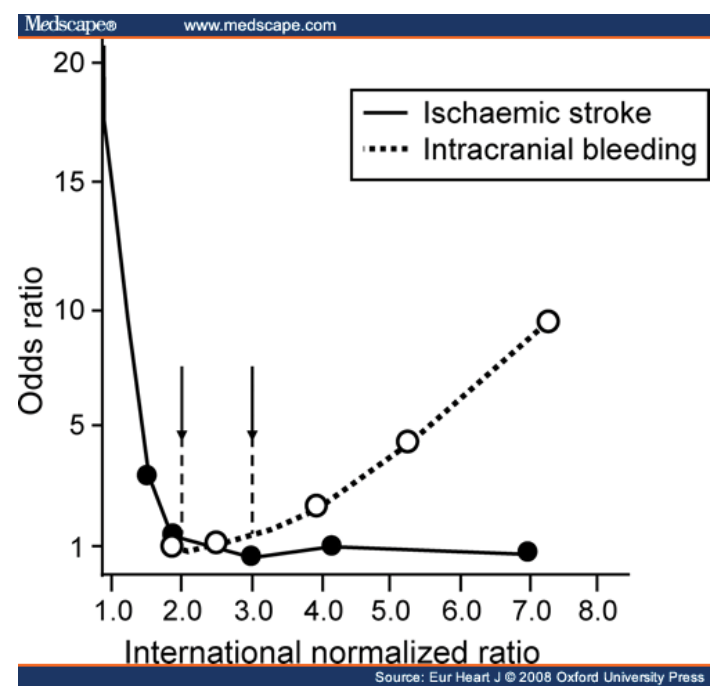

Figure 1: Ischemic and bleeding risk, Eut Heart J, 2008

*Corresponding author: Turiel M, IRCCS - Istituto Ortopedico Galeazzi, Milan Italy, Tel: +390266214945; E-mail: maurizio.turiel@unimi.it

Received January 28, 2015; Accepted February 26, 2015; Published March 05 2015

Citation: Turiel M, Galaverna S, Colombo C, Gianturco L, Stella D (2015) Practical Guide to the New Oral Anticoagulants. J Gen Pract 3: 194. doi: 10.4172/2329-9126.1000194

Copyright: ( 2015 Turiel M, et al. This is an open-access article distributed under the terms of the Creative Commons Attribution License, which permits unrestricted use, distribution, and reproduction in any medium, provided the original author and source are credited. 
Citation: Turiel M, Galaverna S, Colombo C, Gianturco L, Stella D (2015) Practical Guide to the New Oral Anticoagulants. J Gen Pract 3: 194. doi: 10.4172/2329-9126.1000194

Page 2 of 3

\begin{tabular}{|c|c|c|}
\hline $\mathrm{CHA}_{2} \mathrm{DS}_{2}$ Vasc & Score $(0-9)$ & Ischaemic risk \\
\hline $\mathrm{C}=$ Cardiac Failure ${ }^{*}$ & 1 & \multirow{8}{*}{$\begin{array}{c}0=\text { Low risk } \\
1=\text { Intermediate risk } \\
>1=\text { High risk }\end{array}$} \\
\hline $\mathrm{H}=$ Hypertension ${ }^{* *}$ & 1 & \\
\hline$A=$ Age $(\geq 75$ years $)$ & 2 & \\
\hline $\mathrm{D}=$ Diabetes & 1 & \\
\hline S=Stroke (previous) & 2 & \\
\hline $\mathrm{V}=$ Vascular disease $\mathrm{e}^{* * *}$ & 1 & \\
\hline$A=$ Age $(65>$ years $<75)$ & 1 & \\
\hline $\mathrm{Sc}=$ Sex category ${ }^{\star \star * *}$ & 0 or 1 & \\
\hline
\end{tabular}

${ }^{*} \mathrm{EF}<40 \%$ or a history of chronic cardiac failure

${ }^{* *}$ New onset or previous diagnosis

*** Involving aorta and large vessels

${ }^{\star * \star * \star}$ Female $=1$, male $=0$

Table 1: $\mathrm{CHA}_{2} \mathrm{DS}_{2}$ Vasc score.

\begin{tabular}{|c|c|c|}
\hline HAS-BLED & Score $(0-9)$ & Bleeding risk \\
\hline $\mathrm{H}=\mathrm{Hypertension}^{\circ}$ & 1 & \multirow{7}{*}{$\begin{array}{c}<2=\text { Low risk } \\
2=\text { Intermediate risk } \\
>2=\text { High risk }\end{array}$} \\
\hline $\begin{array}{c}A=\text { Abnormal liver/renal } \\
\text { function }{ }^{\circ \circ}\end{array}$ & 1 or 2 & \\
\hline $\mathrm{S}=$ Stroke & 1 & \\
\hline $\mathrm{B}=$ Bleeding $^{\circ \circ 0}$ & 1 & \\
\hline L=Labile INR ${ }^{\circ 00 \circ}$ & 1 & \\
\hline $\mathrm{E}=\mathrm{E}$ Iderly ${ }^{00000}$ & 1 & \\
\hline $\mathrm{D}=$ Drugs/alcohol ${ }^{000000}$ & 1 or 2 & \\
\hline
\end{tabular}

$\mathrm{SBP}>160 \mathrm{mmHg}$

${ }^{\circ} \mathrm{AST} / \mathrm{ALT}>3$ times normal values, or serum creatinine $>2.27 \mathrm{mg} / \mathrm{dL}$

${ }^{\circ 0}$ Prior or predisposition

${ }^{\circ 00}$ Time in therapeutic range $<60 \%$ )

${ }^{\circ 0000} \mathrm{Age}>65$ years

00000 FANS or alcohol intake $>8$ units/week

Table 2: HAS-BLED score.

\begin{tabular}{|c|c|c|c|}
\hline & RE-LY & ROCKET-AF & ARISTOTLE \\
\hline Drug & Dabigatran & Rivaroxaban & Apixaban \\
\hline Dose & 150 mg, 110 mg b.i.d. & $\begin{array}{c}20 \text { mg/day (15 mg/ } \\
\text { day) }\end{array}$ & $5 \mathrm{mg}(2.5 \mathrm{mg})$ b.i.d \\
\hline Patients & 18111 & 14264 & 18201 \\
\hline $\begin{array}{c}\text { Mean } \\
\text { CHA2DS2Vasc }\end{array}$ & 2.1 & 3.5 & 2.1 \\
\hline $\begin{array}{l}\text { Primary } \\
\text { endpoint } \\
\text { (stroke, } \\
\text { systemic } \\
\text { embolism) } \\
\text { (\%/y) }\end{array}$ & $\begin{array}{c}\text { Dabigatran } 110 \mathrm{mg}: \\
1.53 \% \text { (not worse } \\
\text { than warfarin) } \\
\text { Dabigatran } 150 \mathrm{mg}: \\
1.11 \% \text { (superior to } \\
\text { warfarin) } \\
\text { Warfarin: } 1.69 \%\end{array}$ & $\begin{array}{c}\text { Rivaroxaban } 20 \mathrm{mg}: \\
1.7 \% \\
\text { Warfarin: } 2.2 \% \\
\\
\text { (P<0.001 inferiority; } \\
0.12 \text { superiority } \\
\text { intention-to-treat) }\end{array}$ & $\begin{array}{c}\text { Apixaban } 5 \mathrm{mg} \text { : } \\
1,27 \% \\
\text { Warfarin: } 1,60 \% \\
\\
(\mathrm{P}<0.001 \text { non- } \\
\text { inferiority; } \mathrm{P}<0.01 \\
\text { superiority) }\end{array}$ \\
\hline $\begin{array}{l}\text { Hemorrhagic } \\
\text { stroke }(\% / y)\end{array}$ & $\begin{array}{c}\text { Dabigatran } 110 \mathrm{mg}: \\
0.12 \% \\
\text { Dabigatran } 150 \mathrm{mg}: \\
0.10 \% \\
\text { Warfarin } 0.38 \% \\
\\
P<0.0001\end{array}$ & $\begin{array}{c}\text { Rivaroxaban } 20 \mathrm{mg}: \\
0.26 \% \\
\text { Warfarin: } 0.44 \% \\
\\
\mathrm{P}=0.024\end{array}$ & $\begin{array}{l}\text { Apixaban } 5 \mathrm{mg} \text { : } \\
0,24 \% \\
\text { Warfarin: } 0,47 \% \\
\quad P<0.001\end{array}$ \\
\hline $\begin{array}{c}\text { Major bleeding } \\
(\% / y)\end{array}$ & $\begin{array}{c}\text { Dabigatran } 110 \mathrm{mg}: \\
2.87 \% \\
\text { Dabigatran } 150 \mathrm{mg}: \\
3.32 \% \\
\text { Warfarin: } 3.57 \% \\
\\
P=0.003(110 \mathrm{mg}) \\
P=0.32(150 \mathrm{mg})\end{array}$ & $\begin{array}{c}\text { Rivaroxaban } 20 \mathrm{mg}: \\
3.60 \% \\
\text { Warfarin } 3.45 \% \\
\\
\mathrm{P}=0.58\end{array}$ & $\begin{array}{l}\text { Apixaban } 5 \text { mg: } \\
2.13 \% \\
\text { Warfarin: } 3.45 \% \\
\quad P<0.001\end{array}$ \\
\hline
\end{tabular}

Table 3: Results of the RE-LY, ROCKET-AF and ARISTOTLE trials.

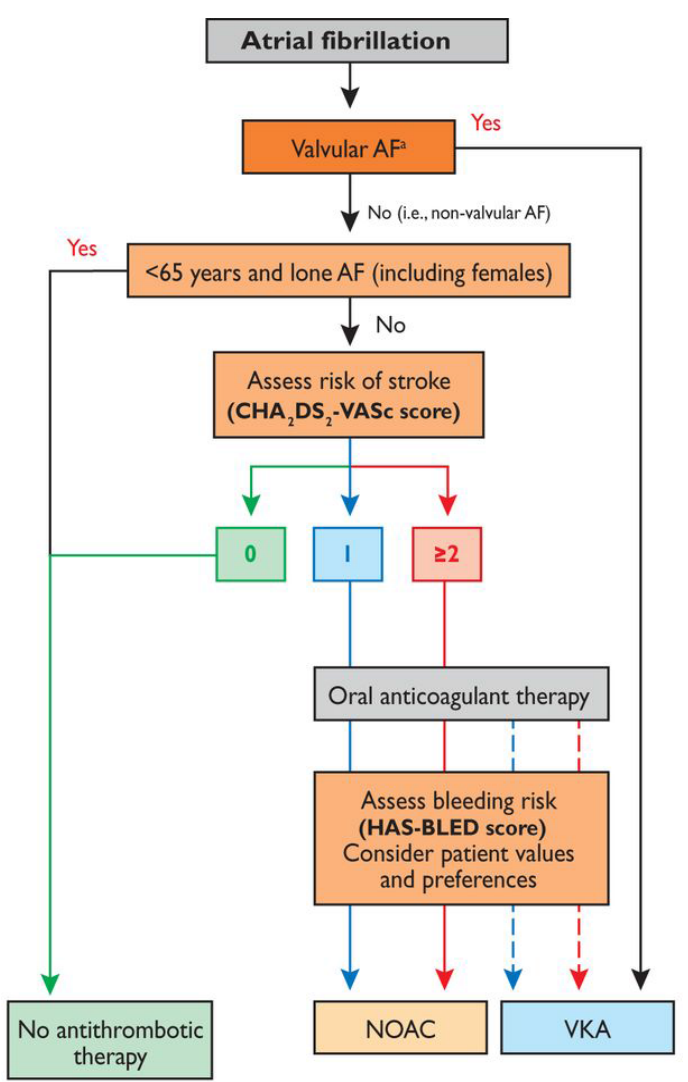

Antiplatelet therapy with aspirin plus clopidogrel, or-less effectively-aspirin only, should be considered in patients who refuse any OAC, or cannot tolerate anticoagulants for reasons unrelated to bleeding. If there are contraindications to OAC or antiplatelet therapy, left atrial appendage occlusion, closure or excision may be considered.

Colour: $\mathrm{CHA}_{2} \mathrm{DS}_{2}-\mathrm{VASc}$; green $=0$, blue $=1$, red $\geq 2$.

Line: solid = best option; dashed = alternative option.

$\mathrm{AF}=$ atrial fibrillation; $\mathrm{CHA}_{2} \mathrm{DS}_{2}-\mathrm{VASc}=$ see text; $\mathrm{HAS}-\mathrm{BLED}=$ see text;

NOAC $=$ novel oral anticoagulant; $\mathrm{OAC}=$ oral anticoagulant;

VKA = vitamin $\mathrm{K}$ antagonist.

ancludes rheumatic valvular disease and prosthetic valves.

Figure 2: ESC flow chart of oral anticoagulation in atrial fibrillation.

- $\quad$ Vit. K inhibitor on the basis of INR

- $\quad$ Direct thrombin inhibitor (dabigatran)

- Oral factor Xa inhibitor (rivaroxaban, apixaban).

7) In patients with a CHADS VASc score of 1, antithrombotic therapy is recommended using one of the following:

- Vit. K inhibitor on the basis of INR

- $\quad$ Direct thrombin inhibitor (dabigatran)

- Oral factor Xa inhibitor (rivaroxaban, apixaban).

If a patient rejects dicumarol or NOAC therapy, double antiplatelet therapy should be considered: ASA 75-100 mg and clopidogrel $75 \mathrm{mg}$ in the case of low bleeding risk, or ASA 75-325 mg alone (less effective) (class IIa B).

The choice of NOAC should be guided by a risk/benefit evaluation, clinical profile, and concomitant therapies. After prescription, a careful follow-up is essential: the first after 30 days, and then every three months. 
Citation: Turiel M, Galaverna S, Colombo C, Gianturco L, Stella D (2015) Practical Guide to the New Oral Anticoagulants. J Gen Pract 3: 194. doi: 10.4172/2329-9126.1000194

Page 3 of 3

It is necessary to evaluate:

- haemoglobin, renal and liver function

- $\quad$ indications for proton pump inhibitors

- $\quad$ the patients' educational level

- patient compliance

- previous ischaemic/hemorrhagic events

- $\quad$ any side effects

The European Heart Rhythm Association (EHRA) [8] recommends using a "Patient Card".

NOACs do not require routine coagulation monitoring; however, a quantitative evaluation of drug exposure and anticoagulation effect may be necessary in emergency situations.

\section{References}

1. Turpie AG (2008) New oral anticoagulants in atrial fibrillation. Eur Heart J 29: $155-165$.

2. Kirchhof P, Ammentorp B, Darius H, De Caterina R, Le Heuzey, et al. (2014) Management of atrial fibrillation in seven European countries after the publication of the 2010 ESC Guidelines on atrial fibrillation: primary results of the PREvention oF thromboemolic eventsa "European Registry in Atrial Fibrillation (PREFER in AF). Europace 16(1): 6-14.

3. Dzeshka, Mikhail S, Deirdre A. Lane, Gregory YH Lip (2014) Stroke and Bleeding Risk in Atrial Fibrillation: Navigating the Alphabet Soup of Risk Score Acronyms (CHADS2, CHA2DS2 VASc, R2CHADS2, HAS BLED, ATRIA, and More)." Clinical Cardiology 37.10: 634-644.

4. Connolly SJ, Ezekowitz MD, Yusuf S, Eikelboom J, Oldgren J, et al. (2009) Dabigatran versus warfarin in patients with atrial fibrillation. N Engl J Med 361 : 1139-1151.

5. Patel MR, Mahaffey KW, Garg J, Pan G, Singer DE, et al. (2011) Rivaroxaban versus warfarin in nonvalvular atrial fibrillation. N Engl J Med 365: 883-891.

6. Granger CB, Alexander JH, McMurray JJ, Lopes RD, Hylek EM, et al. (2011) Apixaban versus warfarin in patients with atrial fibrillation. $\mathrm{N}$ Engl J Med 365: 981-992.

7. Camm AJ, Lip GY, De Caterina R, Savelieva I, Atar D, et al. (2012) 2012 focused update of the ESC Guidelines for the management of atrial fibrillation An update of the 2010 ESC Guidelines for the management of atrial fibrillation developed with the special contribution of the European Heart Rhythm Association. European Heart Journal 33(21): 2719-2747.

8. Heidbuchel H, Verhamme P, Alings M, Antz M, Hacke W, et al. (2013) EHRA Practical Guide on the use of new oral anticoagulants in patients with nonvalvular atrial fibrillation: executive summary. European Heart Journal 34(27) 2094-2106. 